\title{
Structure and Content of Drug Monitoring Advices Included in Discharge Letters at Interfaces of Care: Exploratory Analysis Preceding Database Development
}

Benedict Morath ${ }^{1,2,3}$; Katharina Wien ${ }^{1,2}$; Torsten Hoppe-Tichy ${ }^{2,3}$, Dr rer nat; Walter Emil Haefeli ${ }^{1,2}$, MD, FBPhS; Hanna Marita Seidling ${ }^{1,2}$, PD Dr sc hum

${ }_{1}^{1}$ Department of Clinical Pharmacology and Pharmacoepidemiology, Heidelberg University Hospital, Heidelberg University, Heidelberg, Germany
${ }^{2}$ Cooperation Unit Clinical Pharmacy, Heidelberg University Hospital, Heidelberg University, Heidelberg, Germany
${ }^{3}$ Hospital Pharmacy, Heidelberg University Hospital, Heidelberg University, Heidelberg, Germany

\section{Corresponding Author:}

Hanna Marita Seidling, PD Dr sc hum

Department of Clinical Pharmacology and Pharmacoepidemiology

Heidelberg University Hospital

Heidelberg University

Im Neuenheimer Feld 410

Heidelberg, 69120

Germany

Phone: 4962215638736

Fax: 496221564642

Email: hanna.seidling@med.uni-heidelberg.de

\section{Abstract}

Background: Inadequate drug monitoring of drug therapy after hospital discharge facilitates adverse drug events and preventable hospital readmissions.

Objective: This study aimed to analyze the structure and content of drug monitoring advices of a representative sample of discharge letters as a basis for future electronic information systems.

Methods: On 2 days in November 2016, all discharge letters of 3 departments of a university hospital were extracted from the hospital information system. The frequency, content, and structure of drug monitoring advices in discharge letters were investigated and compared with the theoretical monitoring requirements expressed in the corresponding summaries of product characteristics (SmPC). The quality of the drug monitoring advices in the discharge letters was rated with the domains of an adapted systematic instructions for monitoring (SIM) score.

Results: In total, 154 discharge letters were analyzed containing 1180 brands (240 active pharmaceutical substances), of which $50.42 \%(595 / 1180)$ could theoretically be amended with a monitoring advice according to the SmPC. In reality, 40 discharge letters $(26.0 \%, 40 / 154)$ contained a total of 66 monitoring advices for 57 brands $(4.83 \%, 57 / 1180)$, comprising 18 different monitoring parameters. Drug monitoring advices only addressed mean 1.9 (SD 0.8) of the 7 domains of the SIM score and frequently did not address reasons for monitoring $(86 \%, 57 / 66)$, the timing of monitoring, that is, the start $(76 \%$, 50/66), the frequency $(94 \%, 63 / 66)$, the stop $(95 \%, 63 / 66)$, and how to react $(83 \%, 55 / 66)$.

Conclusions: Drug monitoring advices were mostly absent in discharge letters and a gold standard for appropriate drug monitoring advices was lacking. Hence, more effort should be put in the development of tools that facilitate easy presentation of clinically meaningful drug monitoring advices at the point of care.

(JMIR Med Inform 2019;7(2):e10832) doi: 10.2196/10832

\section{KEYWORDS}

drug monitoring; patient discharge summaries; transition of care 


\section{Introduction}

\section{Background}

Adverse drug events (ADE) frequently occur after the patient transitions across interfaces of care, thus making patients prone to unintended outcomes such as hospital readmissions $[1,2]$. Indeed, up to $10 \%$ of all hospital readmissions occur as a consequence of ADE, and nearly 1 in 4 of these ADE is caused by drugs just started during the index hospitalization [1,3-5]. Since during hospitalization, more than $95 \%$ of all prehospital drug therapies are modified, appropriate follow-up monitoring is particularly important [6-9]. Furthermore, in the discharge medication, over half of the drugs are newly prescribed during hospitalization, emphasizing the need for closer monitoring during the initial postdischarge phase [8]. However, after hospital discharge, monitoring of safety (ADE) and efficacy is often lacking, thus causing potentially preventable readmissions [10]. Interestingly, in the ambulatory setting, preventable ADE resulting from inadequate monitoring and leading to hospitalization are more likely associated with commonly prescribed drugs such as drugs with a cardiovascular indication [1,3,11-13]. For instance, about one-third of patients treated with angiotensin-converting-enzyme (ACE) inhibitors do not undergo serum creatinine and potassium controls at least yearly; although, it is well established that monitored patients experience ADE less often [14-17].

\section{Objectives}

Hence, it appears useful to include structured and comprehensive drug monitoring advices in discharge letters concerning the safety and efficacy of drug therapy to support general practitioners with drug therapy monitoring and ensure a safe patient transfer across the interfaces of care. Today, the current state of drug monitoring recommendations at interfaces is not well known and except for specific diseases or drugs, a comprehensive and prospectively evaluated gold standard for evidence-based drug monitoring advices is lacking [18,19]. As a first step to develop and subsequently provide suitable drug monitoring advices at interfaces of care, we performed an exploratory analysis of the structure and the patterns of current drug monitoring advices in discharge letters and compared this information with the statutory information provided in the pertinent summary of product characteristics (SmPC).

\section{Methods}

\section{Context}

We analyzed an exploratory sample of consecutive discharge letters of 3 major departments of a large university hospital to determine the number, structure, and content of the drug monitoring advices that are currently provided in daily practice. Therefore, discharge letters of the divisions of hemato-oncology, gastroenterology, cardiology, endocrinology, general medicine, psychosomatics, visceral surgery, vascular surgery, cardiac surgery, urology, and neurology were included in the analysis. Although a German drug monitoring guideline was published in 2013 by the German College of General Practitioners and Family Physicians, a comprehensive and prospectively evaluated gold standard for evidence-based drug monitoring advices in different settings of care is not established at present in Germany [20]. Therefore, the information in discharge letters was compared with the generic drug monitoring parameters of the SmPC. This study was approved by the responsible Ethics Committee of the Medical Faculty of Heidelberg University (S-402/2016).

\section{Setting and Data Collection of Drug Monitoring Parameters in the Discharge Letter}

As a point prevalence analysis, all final discharge letters of the departments of, surgery, internal medicine, and neurology that were issued on November 15 and November 16 of the year 2016 and stored in the hospital information system were screened by 1 author. The departments were chosen to cover a broad spectrum of medications of different specialties and generate a representative overview. All discharge letters containing a discharge medication were selected, printed, and pseudonymized by blacking data of the attending physicians and the patient and attributing a consecutive number code to every letter.

The entire discharge letter was independently read by 2 investigators and screened for drug monitoring advices. The following information was extracted into a predefined Microsoft Excel (Microsoft Corporation) sheet with the following categories: Code of the discharge letter, name of all drugs listed as discharge medication including their strength, dosage, and additional information such as administration advices, as well as potential drug monitoring advices with their content and placement in the letter (eg, directly adjunct to a drug or included in the prose text).

A drug monitoring advice was defined as a statement that was explicitly (eg, "please monitor serum potassium under ramipril therapy") or by placement (ie, proximity) connected with the recommended drug treatment at discharge. Second, a drug monitoring advice needed to explicitly state tests that should be performed (eg, electrocardiogram) or parameters that should be checked (eg, potassium) either in terms of safety and ADE monitoring (eg, liver function test to detect hepatotoxicity) or in terms of efficacy (eg, target low-density lipoprotein values to identify poor or nonresponders).

We did not differentiate in drug monitoring advices for newly prescribed drugs and those that were already on the patients' medication list at the time of hospital admission.

\section{Structure and Content of Drug Monitoring Advices in Discharge Letters}

To determine the structure and content of current drug monitoring advices, the drug monitoring advices were independently categorized by 2 authors using the domains of an adapted version of the systematic instructions for monitoring (SIM) score [21]. The SIM score contains 7 essential domains of information, which should be addressed in an unequivocal and comprehensive drug monitoring advice: (1) why to monitor, (2) what to monitor, (3) when to start monitoring, (4) how frequently to monitor, (5) what to look for, that is, target values in terms of drug efficacy or specific ADE such as laboratory changes, (6) how to respond to findings, and (7) when to stop drug monitoring. When analyzing the drug monitoring advices, 
we specified for every category whether it was included in the drug monitoring advice ( $=1$ point) or not ( $=0$ points).

\section{Extraction of Summary of Product Characteristics Information}

The SmPC of all brands reported in the discharge medications were independently screened by 2 authors. When no brand name and only an active pharmaceutical substance was provided in the discharge medication, the SmPC of the brand listed in the hospital formulary was screened because this was the last specific brand the patient received. All eligible text passages concerning drug monitoring of the respective brands were transferred into an excel sheet once a consensus of the 2 reviewers was reached. If consensus was not reached, a third reviewer was involved.

In analogy to the discharge letters, a drug monitoring advice was defined as a parameter that should be measured or a test that should invariably be performed for safety or efficacy reasons at a given time during or after the treatment. Extracted drug monitoring parameters and tests are available in Multimedia Appendix 1.

\section{Analysis and Statistics}

Drug monitoring parameters and tests were rated as concordant in discharge letters and the $\mathrm{SmpC}$ if (1) the drug monitoring parameter or test was stated explicitly in the SmPC and the discharge letter, for example, "measure potassium" or (2) if the SmPC or the discharge letter recommended drug monitoring parameters or tests that were related to each other. As an example, when the SmPC recommended potassium controls and the drug monitoring advices in the discharge letter recommended controls of electrolytes, these drug monitoring advices were also rated as concordant. The allocation of monitoring parameters was done independently by 2 investigators. The frequency of drug monitoring parameters and tests was determined and averages with SDs were calculated using Microsoft Excel. Cohen kappa was calculated to determine interrater reliability of the SIM score rating.

\section{Results}

\section{Characteristics of the Included Discharge Letters and Discharge Medications}

On the 2 index days, 158 discharge letters were issued and hence screened for inclusion. Yet, 4 of these discharge letters did not contain any discharge medication and were therefore excluded, leaving 154 discharge letters for analysis. There were 34 discharge letters from the surgery department $(22.1 \%, 34 / 154)$, 95 from internal medicine $(61.7 \%, 95 / 154)$, and $25(16.2 \%$, $25 / 154$ ) from neurology. Overall, the discharge letters contained 1180 brands referring to 240 different active pharmaceutical substances from 51 different 3-digit anatomical therapeutic chemical code (ATC) groups (see Figure 1), resulting in an average of 7.7 (SD 4.3) brands per discharge letter. The most commonly prescribed brands were antithrombotic agents (B01, $\mathrm{n}=161$ ), drugs for acid-related disorders (A02, $\mathrm{n}=87$ ), agents acting on the renin-angiotensin system $(\mathrm{C} 09, \mathrm{n}=85)$, beta-blocking agents $(\mathrm{C} 07, \mathrm{n}=81)$, and diuretics $(\mathrm{C} 03, \mathrm{n}=80$, Figure 1).

\section{Drug Monitoring Advices Provided in the Discharge Letter}

Overall, 40 discharge letters $(25.9 \%, 40 / 154)$ contained at least 1 drug monitoring advice for, in total, 57 brands (4.83\%, 57/1180), and 29 active pharmaceutical substances (details are shown in Multimedia Appendix 2). Phenprocoumon $(n=6)$, tacrolimus $(n=5)$, and levothyroxine $(n=5)$ were the active pharmaceutical substances most frequently accompanied by a drug monitoring advice (see Table 1). Drug monitoring advices most frequently suggested monitoring of renal function $(n=9)$, trough concentrations $(n=7)$, international normalized ratio $(n=6)$, and blood glucose $(n=6)$. Most drug monitoring advices were solely located in the text $(n=34)$, some were included in the discharge medication $(n=14)$, and the advices were rarely found in both text and discharge medication section $(n=9$; Table 1), leading to a total of 66 drug monitoring advices with a total of 69 suggested drug monitoring parameters and tests (referring to 18 different parameters and tests).

\section{Structure and Content of Drug Monitoring Advices in Discharge Letters}

Of the 66 drug monitoring advices, 20 addressed 1 domain, 29 addressed 2 domains, and 15 addressed 3 domains of the SIM score. Only 1 drug monitoring advice addressed 4 domains (what to monitor, when to start monitoring, how frequently to monitor, and when to stop monitoring), and 1 drug monitoring advice (ie, "we ask for regular endocrinological follow-up controls") was too vague and hence did not meet any of the SIM domains. On average, the drug monitoring advices addressed 1.9 (SD 0.8) domains (see Figure 2).

Nearly all drug monitoring advices $(99 \%, 65 / 66)$ contained a definition of the monitoring parameters or tests that should be performed. Around a quarter of the drug monitoring advices specified when drug monitoring should be started $(24 \%, 16 / 66)$ and what should be looked for (29\%, 19/66, Figure 2). Only few drug monitoring advices gave reasons of drug monitoring, that is, why to monitor $(14 \%, 9 / 66)$, or described which actions to take in case of findings, that is, how to respond to deviations $(17 \%, 11 / 66)$. Adequate timing of drug monitoring was seldom addressed; almost all drug monitoring advices lacked information on the frequency of monitoring, that is, how frequently to monitor $(94 \%, 62 / 66)$ and when monitoring may be stopped $(95 \%, 63 / 66)$. Interrater reliability was very good with a Cohen kappa of 0.89 . 
Figure 1. Most common prescribed drug groups (expressed as 3-digit anatomical therapeutic chemical code class) in 154 consecutive discharge letters of 3 large university departments (internal medicine, neurology, and surgery). ATC: anatomical therapeutic chemical code, RAS: renin-angiotensin system.

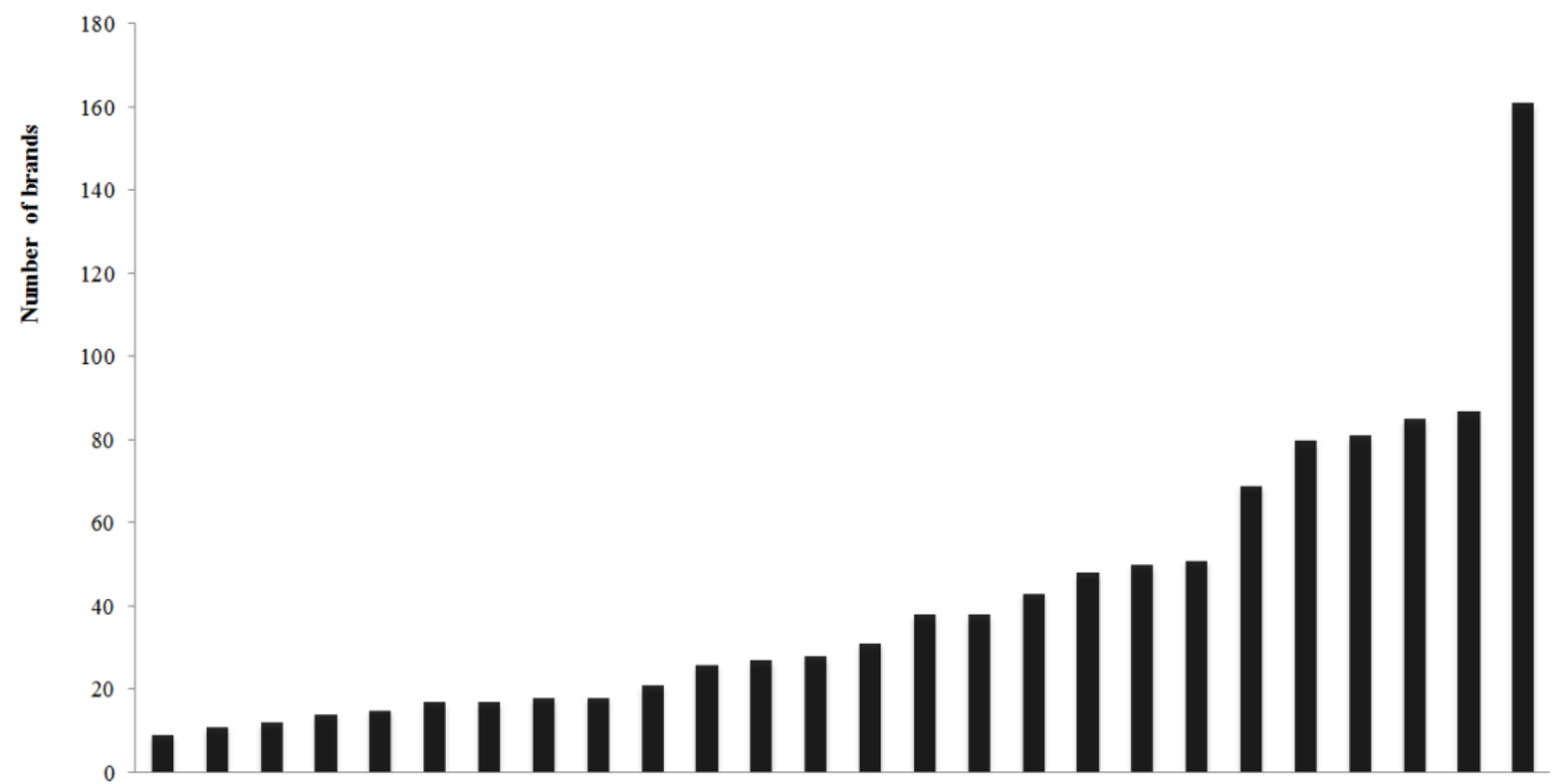

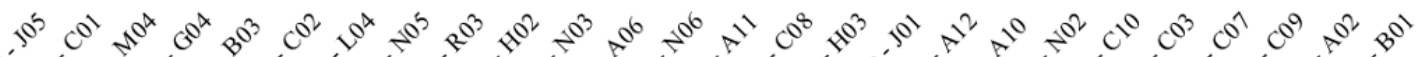

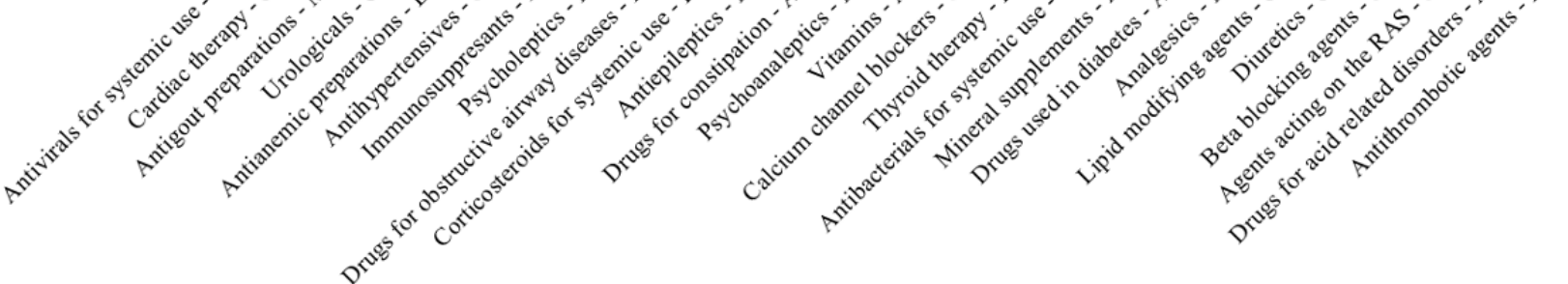

3-digit ATC class 
Table 1. Comparison of the drug monitoring parameters reported in the discharge letters with the monitoring recommendations in the corresponding summary of product characteristics.

\begin{tabular}{|c|c|c|c|c|}
\hline $\begin{array}{l}\text { Active pharmaceutical } \\
\text { substance (frequency) }\end{array}$ & $\begin{array}{l}\text { Location in the discharge } \\
\text { letter (frequency) }{ }^{\mathrm{b}}\end{array}$ & Drug class & $\begin{array}{l}\text { Drug monitoring parameter in } \\
\text { discharge letter (frequency) }\end{array}$ & $\begin{array}{l}\text { Drug monitoring parameters in the } \\
\text { summary of product characteristics }\end{array}$ \\
\hline Apixaban (1/8) & $\mathrm{TXT}^{\mathrm{d}}(1)$ & Factor Xa inhibitor & Blood cell count (1) & Bleeding signs \\
\hline Atorvastatin (3/37) & $\operatorname{MED}^{\mathrm{e}}(3), \operatorname{TXT}(1)$ & $\begin{array}{l}\text { HMG-CoA-reductase } \\
\text { inhibitor }\end{array}$ & $\begin{array}{l}\mathrm{CK}^{\mathrm{g}}(1), \mathrm{LDL}^{\mathrm{h}}(3) \text {, liver func- } \\
\text { tion (1) }\end{array}$ & $\mathrm{CK}$, liver function test \\
\hline Candesartan (1/20) & MED (1), TXT (1) & $\begin{array}{l}\text { Angiotensin-II- recep- } \\
\text { tor antagonist }\end{array}$ & $\begin{array}{l}\text { Blood pressure (1), renal func- } \\
\text { tion (1) }\end{array}$ & $\begin{array}{l}\text { Only in special patient populations } \\
\text { (hypertension and impaired renal } \\
\text { function, heart failure) }\end{array}$ \\
\hline Carvedilol (1/10) & MED (1), TXT (1) & $\begin{array}{l}\text { Nonselective beta } \\
\text { blocker }\end{array}$ & $\begin{array}{l}\text { Blood pressure (1), heart rate } \\
\text { (1) }\end{array}$ & $\begin{array}{l}\text { Only in special patient populations } \\
\text { (heart failure with low blood pres- } \\
\text { sure or ischemic heart disease) }\end{array}$ \\
\hline Cefuroxime (1/4) & TXT (1) & Cephalosporin & Inflammatory parameters (1) & No parameters mentioned \\
\hline Ciclosporin $(2 / 2)$ & MED (1), TXT (1) & Calcineurin inhibitor & Blood concentration (2) & $\begin{array}{l}\text { Serum potassium, serum magne- } \\
\text { sium, serum lipids, uric acid, renal } \\
\text { function, liver function, ciclosporin } \\
\text { concentrations, blood pressure, and } \\
\text { physical examination }\end{array}$ \\
\hline Ciprofloxacin $(2 / 12)$ & TXT (2) & Fluorquinolone & $\begin{array}{l}\text { Inflammatory parameters (2), } \\
\text { renal function (1) }\end{array}$ & No parameters mentioned \\
\hline Clindamycin $(1 / 1)$ & TXT (1) & Lincosamide & Inflammatory parameters (1) & $\begin{array}{l}\text { Blood cell count, liver function test, } \\
\text { and renal function test }\end{array}$ \\
\hline Colecalciferol (1/8) & TXT (1) & Vitamin & Serum calcium (1) & $\begin{array}{l}\text { Calcium in serum and urine, creati- } \\
\text { nine }\end{array}$ \\
\hline Dabigatran etexilate $(1 / 3)$ & $\operatorname{MED}(1)$ & Thrombin inhibitor & $\begin{array}{l}\text { Liver function (1), renal func- } \\
\text { tion (1) }\end{array}$ & $\begin{array}{l}\text { Renal function, signs and symptoms } \\
\text { of bleeding or anemia }\end{array}$ \\
\hline Duloxetine (2/3) & TXT (2) & $\begin{array}{l}\text { Selective serotonin } \\
\text { and norepinephrine } \\
\text { reuptake inhibitor }\end{array}$ & Serum sodium (2) & $\begin{array}{l}\text { Only in special patient populations } \\
\text { (old patients, hypertension, or heart } \\
\text { disease) }\end{array}$ \\
\hline Enoxaparin $(2 / 36)$ & TXT (2) & $\begin{array}{l}\text { Low-molecular- } \\
\text { weight heparin }\end{array}$ & Blood cell count (2) & Platelet count \\
\hline Eplerenone (1/4) & MED (1) & $\begin{array}{l}\text { Mineralocorticoid re- } \\
\text { ceptor antagonist }\end{array}$ & $\begin{array}{l}\text { Renal function (1), electrolytes } \\
\text { (1) }\end{array}$ & Serum potassium \\
\hline Furosemide $(2 / 11)$ & TXT (2) & Loop diuretics & $\begin{array}{l}\text { Renal function (1), electrolytes } \\
\text { (1), body weight (1) }\end{array}$ & $\begin{array}{l}\text { Potassium, sodium, calcium, bicar- } \\
\text { bonate, creatinine, blood urea, uric } \\
\text { acid, and blood glucose }\end{array}$ \\
\hline $\begin{array}{l}\text { Hydrochlorothiazide } \\
(1 / 14)\end{array}$ & MED (1), TXT (1) & Thiazide diuretic & $\begin{array}{l}\text { Renal function (1), electrolytes } \\
\text { (1), }\end{array}$ & $\begin{array}{l}\text { Serum potassium, serum sodium, } \\
\text { and serum magnesium }\end{array}$ \\
\hline Insulin $(6 / 30)$ & TXT (6) & Insulin & Blood glucose (6) & Blood glucose \\
\hline $\begin{array}{l}\text { Pancreatic enzyme sup- } \\
\text { plement }(2 / 6)\end{array}$ & $\mathrm{TXT}(2)$ & Enzymes & Stool consistency (2) & No parameters mentioned \\
\hline Levetiracetam (1/8) & TXT (1) & Antiepileptic & Renal function (1) & Suicidal ideation \\
\hline Levothyroxine (5/34) & MED (1), TXT (5) & Thyroid hormone & Thyroid function (5) & No parameters mentioned \\
\hline Nebivolol (1/7) & TXT (1) & Selective beta blocker & Heart rate (1) & No parameters mentioned \\
\hline Oxcarbazepine (1/1) & TXT (1) & Antiepileptic & Serum sodium (1) & Serum sodium, suicidal ideation \\
\hline Phenprocoumon $(6 / 13)$ & MED (2), TXT (5) & Vitamin $\mathrm{K}$ antagonist & $\operatorname{INR}^{\mathrm{i}}(6)$ & Liver function test, INR \\
\hline Pravastatin (1/16) & MED (1) & $\begin{array}{l}\text { HMG-CoA-reductase } \\
\text { inhibitor }\end{array}$ & LDL (1) & $\begin{array}{l}\text { Only in special patient population } \\
\text { (patients with myopathy, impaired } \\
\text { renal function, hypothyroidism, or } \\
\text { alcohol abuse) }\end{array}$ \\
\hline Ramipril (1/44) & MED (1) & $\begin{array}{l}\text { Angiotensin-convert- } \\
\text { ing-enzyme inhibitor }\end{array}$ & Blood pressure (1) & $\begin{array}{l}\text { Serum potassium, renal function, } \\
\text { and leukocytes }\end{array}$ \\
\hline
\end{tabular}




\begin{tabular}{|c|c|c|c|c|}
\hline $\begin{array}{l}\text { Active pharmaceutical } \\
\text { substance (frequency) }\end{array}$ & $\begin{array}{l}\text { Location in the discharge } \\
\text { letter (frequency) }{ }^{b}\end{array}$ & Drug class & $\begin{array}{l}\text { Drug monitoring parameter in } \\
\text { discharge letter (frequency) }\end{array}$ & $\begin{array}{l}\text { Drug monitoring parameters in the } \\
\text { summary of product characteristics }\end{array}$ \\
\hline Sildenafil $(1 / 2)$ & MED (1) & $\begin{array}{l}\text { Phosphodiesterase } \\
\text { type } 5 \text { inhibitor }\end{array}$ & $\begin{array}{l}\text { Blood pressure (1), heart rate } \\
\text { (1) }\end{array}$ & No parameters mentioned \\
\hline Simvastatin (1/9) & MED (1) & $\begin{array}{l}\text { HMG-CoA-reductase } \\
\text { inhibitor }\end{array}$ & LDL (1) & $\mathrm{CK}$, liver function test \\
\hline Spironolactone $(2 / 13)$ & TXT (2) & $\begin{array}{l}\text { Mineralocorticoid re- } \\
\text { ceptor antagonist }\end{array}$ & $\begin{array}{l}\text { Renal function (1), electrolytes } \\
\text { (1), body weight (1) }\end{array}$ & $\begin{array}{l}\text { Potassium, sodium, calcium, bicar- } \\
\text { bonate, creatinine, blood urea, uric } \\
\text { acid, and acid-base balance }\end{array}$ \\
\hline Tacrolimus (5/6) & MED (5), TXT (2) & Calcineurin inhibitor & Blood concentration (5) & $\begin{array}{l}\text { Electrolytes, liver function, renal } \\
\text { function, fasting blood glucose, } \\
\text { hematological parameters, coagula- } \\
\text { tion, plasma proteins, blood concen- } \\
\text { tration, blood pressure, ECG', neuro- } \\
\text { logic status, and vision }\end{array}$ \\
\hline Torasemide (2/32) & MED (2), TXT (1) & Loop diuretic & $\begin{array}{l}\text { Body weight (1), electrolytes } \\
\text { (1), renal function (1) }\end{array}$ & $\begin{array}{l}\text { Electrolytes, creatinine, uric acid, } \\
\text { blood glucose, lipids, leukocytes, } \\
\text { erythrocytes, and platelets }\end{array}$ \\
\hline
\end{tabular}

${ }^{\text {a }}$ The first number in parenthesis shows the number of active pharmaceutical substances with a drug monitoring advice; the second number in parenthesis indicates the total amount of discharge letters, which had the active pharmaceutical substance included.

${ }^{\mathrm{b}}$ The number in parenthesis indicates how often the drug monitoring advice was located in the text or in the discharge medication.

${ }^{\mathrm{c}}$ The number in parenthesis indicates how often the drug monitoring parameter was recommended for the corresponding active pharmaceutical substance.

${ }^{\mathrm{d}}$ TXT: text.

${ }^{\mathrm{e}} \mathrm{MED}$ : discharge medication.

${ }^{\mathrm{f}}$ HMG-CoA: hydroxymethylglutaryl-coenzyme A.

${ }^{\mathrm{g}} \mathrm{CK}$ : creatine kinase.

${ }^{\mathrm{h}} \mathrm{LDL}$ : low-density lipoprotein.

${ }^{\mathrm{i}}$ INR: international normalized ratio.

${ }^{\mathrm{j}}$ ECG: electrocardiogram.

Figure 2. Overview of the frequency of systematic instructions for monitoring score domains used in the drug monitoring advices of the discharge letters.

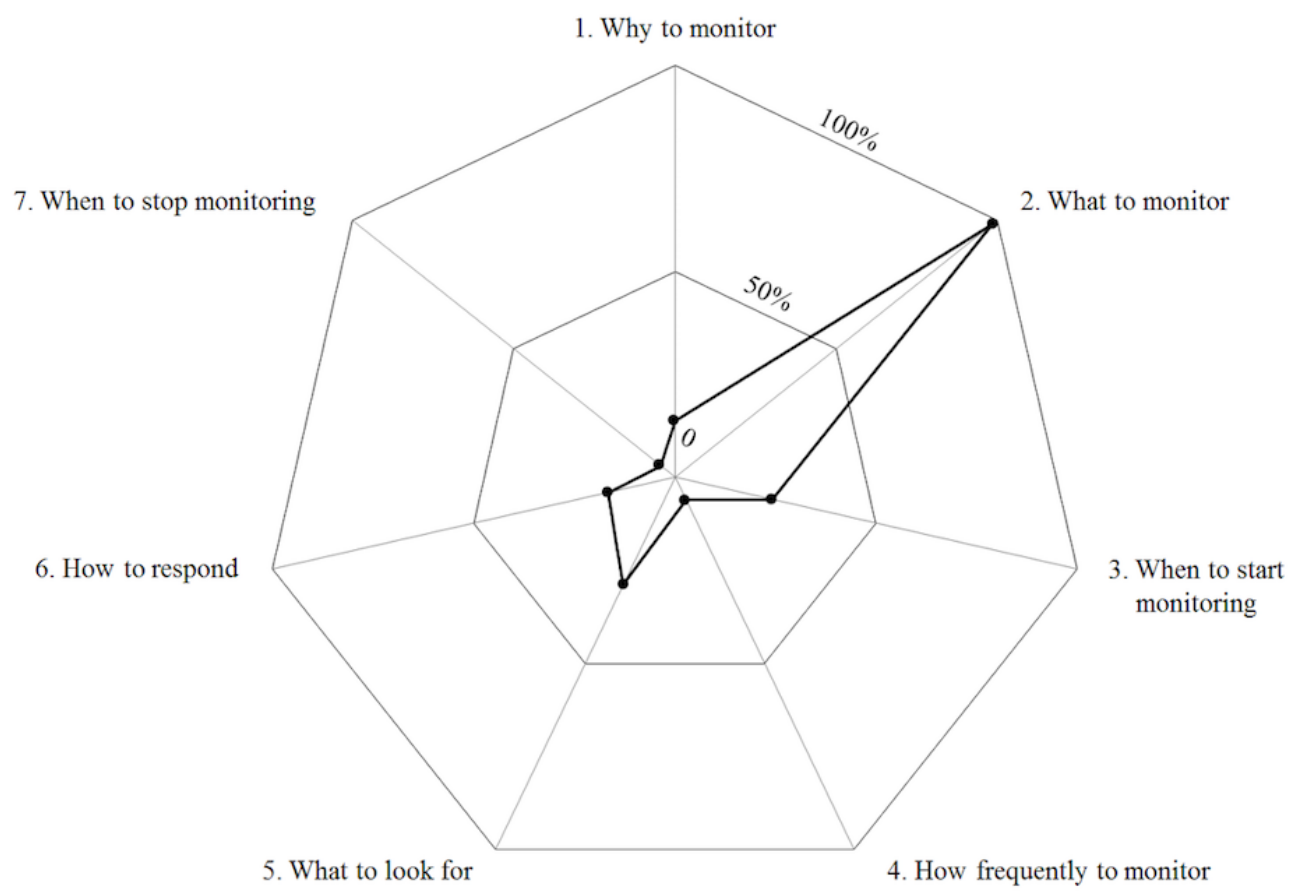




\section{Comparison With Summary of Product Characteristics Information}

For 52 of the 57 brands with an actual drug monitoring advice in the discharge letter, the SmPC also mentioned a drug monitoring advice, but of the 69 drug monitoring parameters and tests mentioned in the discharge letters, only 35 parameters $(51 \%, 35 / 69)$ were also listed in the corresponding SmPC. In contrast, 29 of the $71 \mathrm{SmPC}$ parameters $(41 \%, 29 / 71)$ were included in the discharge letters, whereas the remaining 42 parameters $(59 \%, 42 / 71)$ were not mentioned in the discharge letters at all (Table 1 and Multimedia Appendix 2). However, the SmPC suggested drug monitoring advices for many more drugs. Indeed, for 595 of the 1180 brands (50.42\%) included in the discharge letters (referring to 132 out of 240 active pharmaceutical substances; $55.0 \%$ (132/240), the SmPC contained suggestions for drug monitoring that could be theoretically applied.

\section{Discussion}

\section{Principal Findings}

Drug monitoring advices were provided only for about 1 in 20 brands recommended in the discharge medication and most often did not offer all information domains a "best-practice" monitoring advice should contain. Following the SIM score, the advices only infrequently specified what to look for, why one should monitor, and what should be done in case of finding deviations. Regarding the timing of drug monitoring, a quarter of the advices specified a start of drug monitoring, but only 1 in 20 advices stated a frequency or defined an end of drug monitoring.

\section{Evidence Gap Regarding the Need of Drug Monitoring}

To finally judge the quality of drug monitoring advices and also to subsequently derive an evidence-based information support tool, information on monitoring advices that have been shown to be clinically relevant is needed. Thereby, clinically relevant information might be particularly determined by the severity and probability of the potential ADE or efficacy loss as well as the chances that the ADE or efficacy loss can be reliably detected and prevented by the monitoring activity. The SmPC rather follows a generic approach and suggest up to 10 times more advices than were currently included in the letters. However, it remains unclear whether these advices are all clinically relevant and need to be followed in all patients [21,22]. Conversely, there are first hints suggesting that even the SmPC lacks relevant advices that are included in clinical guidelines. For instance, the 2016 heart failure guideline of the European Society of Cardiology recommends close monitoring of creatinine, serum potassium, and urea upon ACE inhibitor therapy initiation, which was not similarly mentioned in the German ramipril SmPC [23]. Although clinical guidelines might be expected to be a good source for clinically meaningful drug monitoring advices, this aspect is not a standard request for good guideline development, which mainly focuses on proper guideline development methods [24], and preliminary analyses suggest that drug monitoring advices are included only sporadically and certainly not systematically.
In daily practice, there are only few drugs with precise and unambiguous monitoring recommendations in the SmPC, for example, agranulocytosis monitoring with clozapine [25]. However, in most drugs, the monitoring need is vague and a specification requires clinical context factors such as (1) patient characteristics, (2) stage of therapy (eg, dose titration), and (3) comedication. This is also reflected by the discrepancies between the mentioned drug monitoring parameters and tests in the discharge letters and the SmPC in this study, which can be attributed to the evaluation of clinical context factors. As an example, blood glucose monitoring was recommended for a patient under insulin therapy in a discharge letter. This was consistent with the SmPC recommendations, but it also might appear rather obvious and lead to alert fatigue if integrated routinely in discharge letters. Regarding the clinical context factors, the respective patient had had pancreatectomy and therefore a clear clinical indication for close glucose monitoring in the postoperative phase, justifying the explicit drug monitoring advice.

This study therefore supports the hypothesis that there is an evidence gap in terms of a consistent definition of indications for drug monitoring and populations benefitting of it. Therefore, to close this gap, future research should address changes in ADE incidence over time and evaluate protective and risk factors that might have an impact on the need of drug monitoring. There are first approaches to develop such information tools, such as a recent recommendation providing suggestions for drug monitoring of high-risk medicines in primary care, which were derived from a range of guideline sources and expert opinions $[20,26]$.

\section{Concept and Structure of Comprehensive and Practical Drug Monitoring Advices}

If drug monitoring is indicated, the drug monitoring advices should be clearly formulated and support physicians in the development of individual monitoring plans. A comprehensive drug monitoring advice should follow the information clusters suggested in the SIM score [21]. The need of drug monitoring defined by a sole indication of a drug, for example, clozapine therapy, or a combination of clinical context factors define the domains "why to monitor" (SIM score domain 1) and what to monitor (SIM score domain 2). The stage of therapy (eg, drug initiation, maintenance, or tapering) is an important determinant regarding the proper timing of drug monitoring activities and specifies the start (SIM score domain 3), the frequency (SIM score domain 4), and the end of drug monitoring (SIM score domain 7). Timing is a crucial aspect of any monitoring because the risk of ADE varies over time as some drugs have a high risk of ADE early after drug initiation, for example, hyperkalemia with ramipril intake or dosage changes, whereas, other ADE more likely occur after longer time periods, for example, pulmonary toxicity caused by amiodarone [27-30]. The SIM score domain "what to look for" (SIM score domain 5) and "how to respond" (SIM score domain 6) are domains that were rarely addressed and, if addressed, sufficient information was lacking. For instance, the drug monitoring advice "please check liver function" lacks detailed information on what explicitly to look for because drug-induced liver injury occurs in different clinical patterns such as hepatic, cholestatic, or mixed, which 
can easily be detected by characteristic laboratory patterns [31,32].

\section{Limitations of the Study Design}

This study has several limitations. First, a sample of 154 discharge letters was analyzed, which could be deemed as relatively small. To ensure representability, we included consecutive discharge letters of 2 working days rather than deliberately choosing letters of different patient populations; this approach covered a broad range of different brands $(n=1180)$ and a sizeable number of different 3-digit ATC-codes $(n=51)$. Moreover, the sample size was estimated on the basis of previous studies analyzing the quality and structure of drug monitoring advices in drug labels, which had similar or even lower sample sizes [21,22,33]. Second, direct clinical implications of missing drug monitoring parameters neither were nor could have been assessed in this study, and they neither were in the focus of our study. Furthermore, the clinical implications of infrequent drug monitoring are well known, and there is no obvious reason to omit proper monitoring of pharmacotherapy after discharge from tertiary care [3,34]. Therefore, the study focused on the structure and content of drug monitoring advices at interfaces of care to analyze potential areas for improvement and interventions, targeting the problem of infrequent drug monitoring in patient care. Third, we did not consider the date of onset of a specific drug as this information was scarcely available in the discharge letters. ADE of some active pharmaceutical substances (eg, hyperkalemia with ramipril intake) might occur more likely during dosage titration and monitoring periods could be longer, when long-term maintenance doses are taken uneventfully [27,29]. Consequently, it might be possible that the real monitoring need was overestimated or, on the other hand, that drug monitoring advices were not precise enough. Finally, we solely evaluated the drug monitoring advices of one other data source, that is, the SmPC. Yet, as the legally binding document also in terms of drug therapy monitoring, it could be the first reference consulted by prescribers and information therein should be reliable also in this regard.

\section{Conclusions}

Drug monitoring advices were included in discharge letters only for a minority of brands; however, respective SmPC information was broad and unspecific in most parts, suggesting that a future monitoring database should consider not only the drug and its indication but also further patient characteristics, the stage of therapy, and the comedication.

\section{Authors' Contributions}

BM planned the study design, extracted the discharge letters, analyzed the data, and wrote the manuscript. KW analyzed the data and wrote the manuscript. THT planned the study design. He wrote parts of the manuscript and critically revised it. WEH planned the study design, analyzed the data, wrote the manuscript, and critically revised it. HS planned the study design, analyzed the data, wrote the manuscript, and critically revised it.

\section{Conflicts of Interest}

None declared.

\section{Multimedia Appendix 1}

Overview of summary of parameters, tests, and symptoms to monitor mentioned in the summary of product characteristics.

[PDF File (Adobe PDF File), 105KB-Multimedia Appendix 1]

\section{Multimedia Appendix 2}

Overview of the drug monitoring advices recommended in 154 of 158 consecutive discharge letters of a university hospital.

[PDF File (Adobe PDF File), 268KB-Multimedia Appendix 2]

\section{References}

1. Forster AJ, Murff HJ, Peterson JF, Gandhi TK, Bates DW. Adverse drug events occurring following hospital discharge. J Gen Intern Med 2005 Apr;20(4):317-323 [FREE Full text] [doi: 10.1111/j.1525-1497.2005.30390.x] [Medline: 15857487]

2. Forster AJ, Murff HJ, Peterson JF, Gandhi TK, Bates DW. The incidence and severity of adverse events affecting patients after discharge from the hospital. Ann Intern Med 2003 Feb 4;138(3):161-167. [Medline: 12558354]

3. Budnitz DS, Pollock DA, Weidenbach KN, Mendelsohn AB, Schroeder TJ, Annest JL. National surveillance of emergency department visits for outpatient adverse drug events. J Am Med Assoc 2006 Oct 18;296(15):1858-1866. [doi:

10.1001/jama.296.15.1858] [Medline: 17047216]

4. Dormann H, Neubert A, Criegee-Rieck M, Egger T, Radespiel-Tröger M, Azaz-Livshits T, et al. Readmissions and adverse drug reactions in internal medicine: the economic impact. J Intern Med 2004 Jun;255(6):653-663 [FREE Full text] [doi: 10.1111/j.1365-2796.2004.01326.x] [Medline: $\underline{15147529]}$

5. Davies EC, Green CF, Mottram DR, Rowe PH, Pirmohamed M. Emergency re-admissions to hospital due to adverse drug reactions within 1 year of the index admission. Br J Clin Pharmacol 2010 Nov;70(5):749-755 [FREE Full text] [doi: 10.1111/j.1365-2125.2010.03751.x] [Medline: 21039769] 
6. Himmel W, Kochen MM, Sorns U, Hummers-Pradier E. Drug changes at the interface between primary and secondary care. Int J Clin Pharmacol Ther 2004 Feb;42(2):103-109. [Medline: 15180171]

7. Himmel W, Tabache M, Kochen MM. What happens to long-term medication when general practice patients are referred to hospital? Eur J Clin Pharmacol 1996;50(4):253-257. [Medline: 8803514]

8. Grimmsmann T, Schwabe U, Himmel W. The influence of hospitalisation on drug prescription in primary care - a large-scale follow-up study. Eur J Clin Pharmacol 2007 Aug;63(8):783-790. [doi: 10.1007/s00228-007-0325-1] [Medline: 17549465]

9. von Klüchtzner W, Grandt D. Influence of hospitalization on prescribing safety across the continuum of care: an exploratory study. BMC Health Serv Res 2015 May 13;15:197 [FREE Full text] [doi: 10.1186/s12913-015-0844-x] [Medline: 25962594]

10. Kripalani S, LeFevre F, Phillips CO, Williams MV, Basaviah P, Baker DW. Deficits in communication and information transfer between hospital-based and primary care physicians: implications for patient safety and continuity of care. J Am Med Assoc 2007 Feb 28;297(8):831-841. [doi: 10.1001/jama.297.8.831] [Medline: 17327525]

11. Thomsen LA, Winterstein AG, Søndergaard B, Haugbølle LS, Melander A. Systematic review of the incidence and characteristics of preventable adverse drug events in ambulatory care. Ann Pharmacother 2007 Sep;41(9):1411-1426. [doi: 10.1345/aph.1H658] [Medline: 17666582]

12. Kanaan AO, Donovan JL, Duchin NP, Field TS, Tjia J, Cutrona SL, et al. Adverse drug events after hospital discharge in older adults: types, severity, and involvement of Beers Criteria Medications. J Am Geriatr Soc 2013 Nov;61(11):1894-1899 [FREE Full text] [doi: 10.1111/jgs.12504] [Medline: 24116689]

13. Gurwitz JH, Field TS, Harrold LR, Rothschild J, Debellis K, Seger AC, et al. Incidence and preventability of adverse drug events among older persons in the ambulatory setting. J Am Med Assoc 2003 Mar 5;289(9):1107-1116. [Medline: 12622580]

14. Raebel MA, McClure DL, Simon SR, Chan KA, Feldstein A, Andrade SE, et al. Laboratory monitoring of potassium and creatinine in ambulatory patients receiving angiotensin converting enzyme inhibitors and angiotensin receptor blockers. Pharmacoepidemiol Drug Saf 2007 Jan;16(1):55-64. [doi: 10.1002/pds.1217] [Medline: 16470693]

15. Raebel MA, Lyons EE, Andrade SE, Chan KA, Chester EA, Davis RL, et al. Laboratory monitoring of drugs at initiation of therapy in ambulatory care. J Gen Intern Med 2005 Dec;20(12):1120-1126 [FREE Full text] [doi: 10.1111/j.1525-1497.2005.0257.x] [Medline: 16423101]

16. Tjia J, Fischer SH, Raebel MA, Peterson D, Zhao Y, Gagne SJ, et al. Baseline and follow-up laboratory monitoring of cardiovascular medications. Ann Pharmacother 2011 Sep;45(9):1077-1084. [doi: 10.1345/aph.1Q158] [Medline: 21852593]

17. Raebel MA, Ross C, Xu S, Roblin DW, Cheetham C, Blanchette CM, et al. Diabetes and drug-associated hyperkalemia: effect of potassium monitoring. J Gen Intern Med 2010 Apr;25(4):326-333 [FREE Full text] [doi:

10.1007/s11606-009-1228-x] [Medline: 20087674]

18. Hiemke C, Bergemann N, Clement HW, Conca A, Deckert J, Domschke K, et al. Consensus guidelines for therapeutic drug monitoring in neuropsychopharmacology: update 2017. Pharmacopsychiatry 2018 Jan;51(1-02):9-62 [FREE Full text] [doi: 10.1055/s-0043-116492] [Medline: 28910830]

19. Feuerstein JD, Nguyen GC, Kupfer SS, Falck-Ytter Y, Singh S, American Gastroenterological Association Institute Clinical Guidelines Committee. American gastroenterological association institute guideline on therapeutic drug monitoring in inflammatory bowel disease. Gastroenterology 2017 Dec;153(3):827-834. [doi: 10.1053/j.gastro.2017.07.032] [Medline: 28780013]

20. Mainz A, Kötter T, Brockmann S, Egidi G. German Society for General Medicine and Family Medicine. Drug monitoring URL: http://www.degam.de/files/Inhalte/Leitlinien-Inhalte/Dokumente/DEGAM-S1-Handlungsempfehlung/

053-037\%20Medikamentenmonitoring/S1-HE_Medikamentenmonitoring_Langfassung_201406.pdf [accessed 2018-04-09] [WebCite Cache ID 6yXo0PTX4]

21. Ferner RE, Coleman J, Pirmohamed M, Constable SA, Rouse A. The quality of information on monitoring for haematological adverse drug reactions. Br J Clin Pharmacol 2005 Oct;60(4):448-451 [FREE Full text] [doi: 10.1111/j.1365-2125.2005.02440.x] [Medline: 16187979$]$

22. Geerts AF, De Koning FH, Van Solinge WW, De Smet PA, Egberts TC. Instructions on laboratory monitoring in 200 drug labels. Clin Chem Lab Med 2012 Feb 2;50(8):1351-1358. [doi: 10.1515/cclm-2011-0753] [Medline: 22868799]

23. Ponikowski P, Voors AA, Anker SD, Bueno H, Cleland JG, Coats AJ, ESC Scientific Document Group. 2016 ESC Guidelines for the diagnosis and treatment of acute and chronic heart failure: the Task Force for the diagnosis and treatment of acute and chronic heart failure of the European Society of Cardiology (ESC) Developed with the special contribution of the Heart Failure Association (HFA) of the ESC. Eur Heart J 2016 Dec 14;37(27):2129-2200. [doi: 10.1093/eurheartj/ehw128] [Medline: 27206819]

24. Qaseem A, Forland F, Macbeth F, Ollenschläger G, Phillips S, van der Wees P, Board of Trustees of the Guidelines International Network. Guidelines International Network: toward international standards for clinical practice guidelines. Ann Intern Med 2012 Apr 3;156(7):525-531. [doi: 10.7326/0003-4819-156-7-201204030-00009] [Medline: 22473437]

25. Food and Drug Administration. Clozaril - Summary of product characteristics URL: https://www.accessdata.fda.gov/ drugsatfda docs/label/2010/019758s062lbl.pdf [accessed 2019-01-17] [WebCite Cache ID 75UsbGcvy]

26. Erskine D. Specialist Pharmacy Service. 2017 Oct. Suggestions for therapeutic drug monitoring in adults in primary care URL: https://www.sps.nhs.uk/wp-content/uploads/2017/12/Drug-monitoring-final-December-2017a.pdf [accessed 2018-04-05] [WebCite Cache ID 6ySBO6VEp] 
27. Park IW, Sheen SS, Yoon D, Lee SH, Shin GT, Kim H, et al. Onset time of hyperkalaemia after angiotensin receptor blocker initiation: when should we start serum potassium monitoring? J Clin Pharm Ther 2014 Feb;39(1):61-68. [doi: 10.1111/jcpt.12109] [Medline: 24262001]

28. Epstein AE, Olshansky B, Naccarelli GV, Kennedy Jr JI, Murphy EJ, Goldschlager N. Practical management guide for clinicians who treat patients with amiodarone. Am J Med 2016 May;129(5):468-475. [doi: 10.1016/j.amjmed.2015.08.039] [Medline: 26497904]

29. Barber J, McKeever TM, McDowell SE, Clayton JA, Ferner RE, Gordon RD, et al. A systematic review and meta-analysis of thiazide-induced hyponatraemia: time to reconsider electrolyte monitoring regimens after thiazide initiation? Br J Clin Pharmacol 2015 Apr;79(4):566-577 [FREE Full text] [doi: 10.1111/bcp.12499] [Medline: 25139696]

30. Connolly S, Cairns J, Gent M, Roberts R, Yusuf S. Effect of prophylactic amiodarone on mortality after acute myocardial infarction and in congestive heart failure: meta-analysis of individual data from 6500 patients in randomised trials.

Amiodarone Trials Meta-Analysis Investigators. Lancet 1997 Nov 15;350(9089):1417-1424. [Medline: 9371164]

31. Leise MD, Poterucha JJ, Talwalkar JA. Drug-induced liver injury. Mayo Clin Proc 2014 Jan;89(1):95-106. [doi: 10.1016/j.mayocp.2013.09.016] [Medline: 24388027]

32. Fontana RJ, Seeff LB, Andrade RJ, Björnsson E, Day CP, Serrano J, et al. Standardization of nomenclature and causality assessment in drug-induced liver injury: summary of a clinical research workshop. Hepatology 2010 Aug;52(2):730-742 [FREE Full text] [doi: 10.1002/hep.23696] [Medline: 20564754]

33. Nederlof M, Stoker LJ, Egberts TC, Heerdink ER. Instructions for clinical and biomarker monitoring in the summary of product sharacteristics (SmPC) for psychotropic drugs: overview and applicability in clinical practice. J Psychopharmacol 2015 Dec;29(12):1248-1254. [doi: 10.1177/0269881115609016] [Medline: 26464457]

34. Auerbach AD, Kripalani S, Vasilevskis EE, Sehgal N, Lindenauer PK, Metlay JP, et al. Preventability and causes of readmissions in a national cohort of general medicine patients. JAMA Intern Med 2016 Apr;176(4):484-493. [doi: 10.1001/jamainternmed.2015.7863] [Medline: 26954564]

\author{
Abbreviations \\ ACE: angiotensin-converting-enzyme \\ ADE: adverse drug event \\ ATC: anatomical therapeutic chemical code \\ CK: creatine kinase \\ ECG: electrocardiogram \\ HMG-CoA: hydroxymethylglutaryl-coenzyme A \\ INR: international normalized ratio \\ LDL: low-density lipoprotein \\ MED: discharge medication \\ SIM: systematic instructions for monitoring \\ SmPC: summary of product characteristics \\ TXT: text
}

Edited by G Eysenbach; submitted 20.04.18; peer-reviewed by Y Li; comments to author 09.10.18; revised version received 06.11.18;
accepted 10.12.18; published 08.04.19
Please cite as:
Morath B, Wien K, Hoppe-Tichy T, Haefeli WE, Seidling HM
Structure and Content of Drug Monitoring Advices Included in Discharge Letters at Interfaces of Care: Exploratory Analysis Preceding
Database Development
JMIR Med Inform 2019;7(2):e10832
URL: https:///medinform.jmir.org/2019/2/e10832/
doi: $10.2196 / 10832$
PMID: $\underline{30958278}$

CBenedict Morath, Katharina Wien, Torsten Hoppe-Tichy, Walter Emil Haefeli, Hanna Marita Seidling. Originally published in JMIR Medical Informatics (http://medinform.jmir.org), 08.04.2019. This is an open-access article distributed under the terms of the Creative Commons Attribution License (https://creativecommons.org/licenses/by/4.0/), which permits unrestricted use, distribution, and reproduction in any medium, provided the original work, first published in JMIR Medical Informatics, is properly cited. The complete bibliographic information, a link to the original publication on http://medinform.jmir.org/, as well as this copyright and license information must be included. 